RESEARCH NOTE

\title{
Determining Grapevine Canopy Effects on Effective Rainfall in Vineyards
}

\author{
P.A. Myburgh* \\ ARC Infruitec-Nietvoorbij, Private Bag X5026, 7599 Stellenbosch, South Africa
}

Submitted for publication: June 2003

Accepted for publication: October 2003

Key words: canopy, interception, grapevine, rainfall, trellis system

\begin{abstract}
Rainfall interception was determined for six trellis systems in a vineyard at Stellenbosch. Measurements made directly under the canopy and in the centre of the work row were compared to rainfall measured outside the vineyard. Rainfall was measured over two growing seasons from October until March. There was no difference between rainfall in the centre of the work rows and rainfall outside the vineyard. Due to the effect of seasonal increases in leaf area on rainfall that penetrated through the canopy, rainfall interception was estimated from rainfall measured outside the vineyard, as well as day of season when it occurred by means of multiple linear regressions. Since canopy orientation also influenced the amount of water that reached the soil surface, two regression equations were developed that explained $96 \%$ and $89 \%$ of the variation in the amount of water that reached the soil surface under slanting and vertical canopies, respectively. On average $86 \%$ and $80 \%$ of the rainfall landed under slanting and vertical canopies, respectively. Based on the assumption that rainfall on the uncovered fraction of the work row was similar to the rainfall measured outside the vineyard, the calculated weighted mean rainfall over the total area did not differ drastically from actual rainfall. This indicated that canopy effects on rainfall interception in vineyards were relatively small.
\end{abstract}

Rainfall can make a significant contribution to the water supply of vineyards in the Mediterranean climate areas of the Western Cape, especially during dry summers. The role of rainfall could also be important in semi-arid areas where summer rainfall is low and infrequent. In order to manage limited irrigation water optimally, irrigation schedules should be adapted when rain occurs during the growing season of grapevines. This can only be done accurately if the effectiveness of the rainfall is known.

Effective rainfall can be defined as that portion of rainfall that contributes to meeting the evapotranspiration requirement of a crop (Dent et al., 1988). Although it is accepted that any rainfall will effectively reduce vineyard evapotranspiration (Van Zyl, 1981), the actual reduction has not been quantified. Overcast conditions, normally associated with rain, can cause a substantial reduction in grapevine transpiration that will also affect the soil water balance (Myburgh, 1998). The amount of rain that actually becomes part of the soil water balance in the root zone is a controversial matter. Since water in topsoil layers will evaporate within a day or two under hot summer conditions encountered in South Africa, it was proposed that rainfall less than $25 \mathrm{~mm}$ /day should be ignored in the water balance of vineyards (Van Zyl, 1981). On the other hand, it has been suggested that rainfall in excess of $10 \mathrm{~mm} /$ day to 15 $\mathrm{mm}$ /day should be regarded as equal to irrigations of similar magnitude applied by means of micro irrigation systems (Van Zyl, 1981). Another approach is to regard all rainfall as effective in replenishing soil water content of the root zone to field capacity and to assume that excess rainfall is not part of the soil water balance (Green, 1985). This implies that effective rainfall will be high- er for a deep root system in a dry soil compared to a shallow root system in a dry soil. A large amount of rainfall on dry soil with a high water-holding capacity will also be more effective compared to the same amount on dry soil with a low water-holding capacity.

Highly variable factors such as soil water content, soil surface condition, rainfall intensity, angle of rainfall incidence, rain direction with respect to row direction, as well as canopy cover and density, complicate exact prediction of the fraction of rain that will penetrate the soil. Due to the many variables that have to be considered, quantification of effective rainfall in South African vineyards has not yet been attempted. The aim of this study was to determine to what extent grapevine canopies would influence effective rainfall in vineyards.

\section{MATERIALS AND METHODS}

The field trial was carried out in a seventeen-year-old Chenin blanc/99 Richter vineyard on the Nietvoorbij experimental farm near Stellenbosch. Grapevines were planted $3.0 \mathrm{~m}$ by $1.5 \mathrm{~m}$ in a north-south direction and trained onto six different trellising systems. Rainfall was measured under these trellising systems representing slanting and vertical canopy orientations. Slanting systems consisted of a $1.5 \mathrm{~m}$ slanting trellis and a gable trellis (Zeeman, 1981), whereas vertical trellises consisted of a 3-wire vertical hedge, a 5-wire lengthened Perold (Archer \& Booysen, 1987) and a vertical hedge modified to a Lyre trellis (Volschenk $\&$ Hunter, 2001). Bush vine canopies were regarded as slanting for the purpose of this study. Since the vineyard was originally established for demonstration purposes, the different trellis systems were not replicated spatially.

*E-mail address: philipm@infruit.agric.za

Acknowledgements: Partial funding by Winetech as well as technical assistance of the Soil Science staff at ARC Infruitec-Nietvoorbij. 
Rainfall was measured outside the vineyard on the northern and southern sides $1.5 \mathrm{~m}$ above the soil surface, using plastic rain meters. In the vineyard, rainfall was measured at two positions in the centre of the work row and at two positions between grapevines in the row. Plastic rain meters were installed level with the soil surface inside $150 \mathrm{~mm}$ diameter steel sleeves. Rainfall was recorded on a daily basis from October until March during the 1994/95 and 1995/96 seasons. Rain meters were inspected regularly to remove dead leaves and other debris. Rainfall interception was defined as the difference between actual rainfall outside the vineyard and rainfall measured directly under the canopies. To quantify grapevine vigour, cane mass was determined at pruning in July. Statgraphics ${ }^{\circledR}$ was used to determine relationships between parameters by means of linear regression.

\section{RESULTS AND DISCUSSION}

For all the trellis systems cane mass per grapevine varied between $0.9 \mathrm{~kg}$ (bush vines) and $1.2 \mathrm{~kg}$ (1.5 m slanting trellis). This indicated that, under conditions of this study, grapevine vigour was strong for the bush vines and vertical trellis systems, whereas it could be regarded as moderate for the $1.5 \mathrm{~m}$ slanting and gable trellises (Zeeman, 1981). For production of table and dried grapes on slanting systems, more vigour - as quantified by cane mass would be required (Saayman \& Lambrechts, 1995).

Due to the Mediterranean climate at Stellenbosch, rainfall is expected to be low and infrequent during the growing season. During the two seasons, rainfall varied between $0.3 \mathrm{~mm} /$ day and 38 $\mathrm{mm} /$ day. With the exception of one day, rainfall was less than 10 $\mathrm{mm} /$ day for the 18 days on which rain occurred from October until March during the 1994/95 season. Compared to the long-term mean (22 years) rainfall of $172 \mathrm{~mm}$ at Nietvoorbij, total rainfall

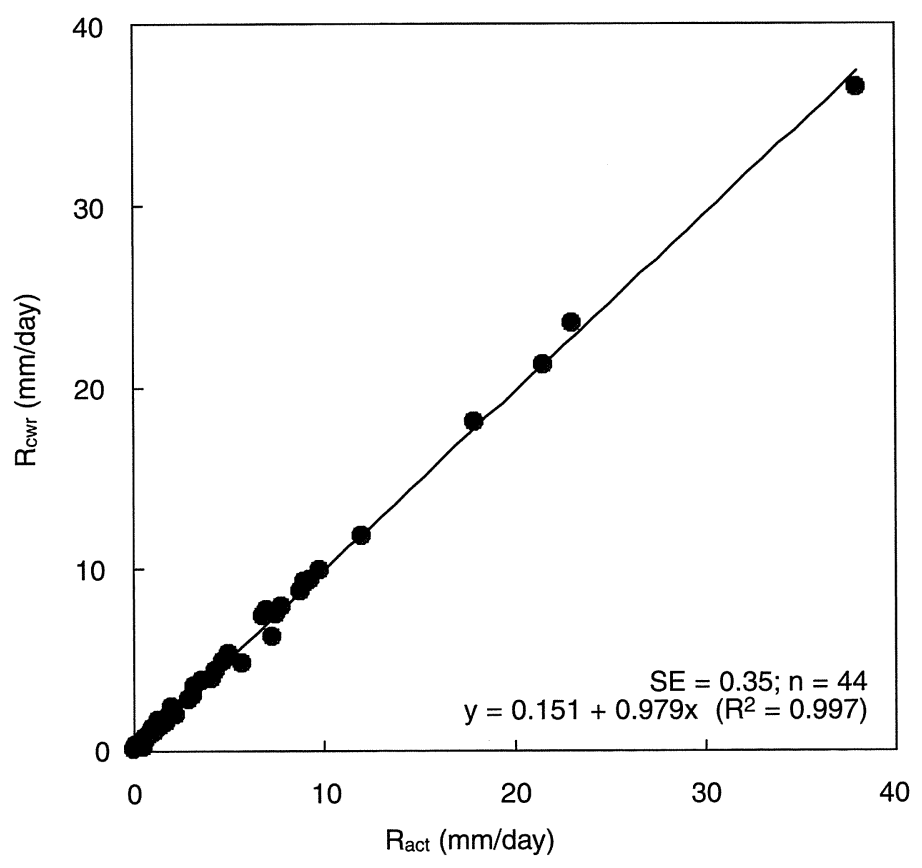

FIGURE 1

Relationship between mean daily rainfall measured at the centres of work rows of different grapevine trellises $\left(\mathrm{R}_{\mathrm{cwr}}\right)$ and actual rainfall measured outside the vineyard $\left(R_{\mathrm{act}}\right)$. Data were collected over two seasons at Nietvoorbij, Stellenbosch. from October until March amounted to only $74 \mathrm{~mm}$, indicating that it was an exceptionally dry season. During the 1995/96 season rainfall exceeded $10 \mathrm{~mm}$ on $27 \%$ of the 26 days that rainfall was recorded. Furthermore, the total rainfall of $269 \mathrm{~mm}$ was substantially higher than the long-term mean for October until March.

The standard error of $0.35 \mathrm{~mm}$ indicated that there were practically no differences at any stage of the season between the amount of water that landed on the soil surface in the centre of the work row and daily rainfall measured outside the vineyard, irrespective of trellis system (Fig. 1). These results indicated that trellis system, canopy development over the season, rainfall intensity and angle of incidence did not influence the amount of water that fell in the centre of the work rows. This will apply to the fraction of the work row not covered by the canopies, except when rainfall is more or less perpendicular to the row, and low angles of incidence causes rainfall shading on the leeward side. Furthermore, more vigourous grapevines on slanting canopies are bound to intercept rain over a larger fraction of the work row than the ones in this study.

The amount of water that reached the soil surface below grapevine canopies tended to be less than rainfall outside the vineyard. In general, less rain reached the soil surface under vertical canopies compared to the slanting canopies (Fig. 2). More rain was probably retained by a higher number of leaf layers directly above the rain meters in the case of vertical canopies compared to the less dense slanting canopies. Values close to the 1:1 line in Figure 2 were obtained early in the growing season when the canopies had less effect on rainfall interception. Furthermore, there were practically no differences in the amount of water that reached the soil surface under the canopies of the three slanting systems. A similar trend was found in the case of the vertical systems. Perusal of the data also revealed that rainfall

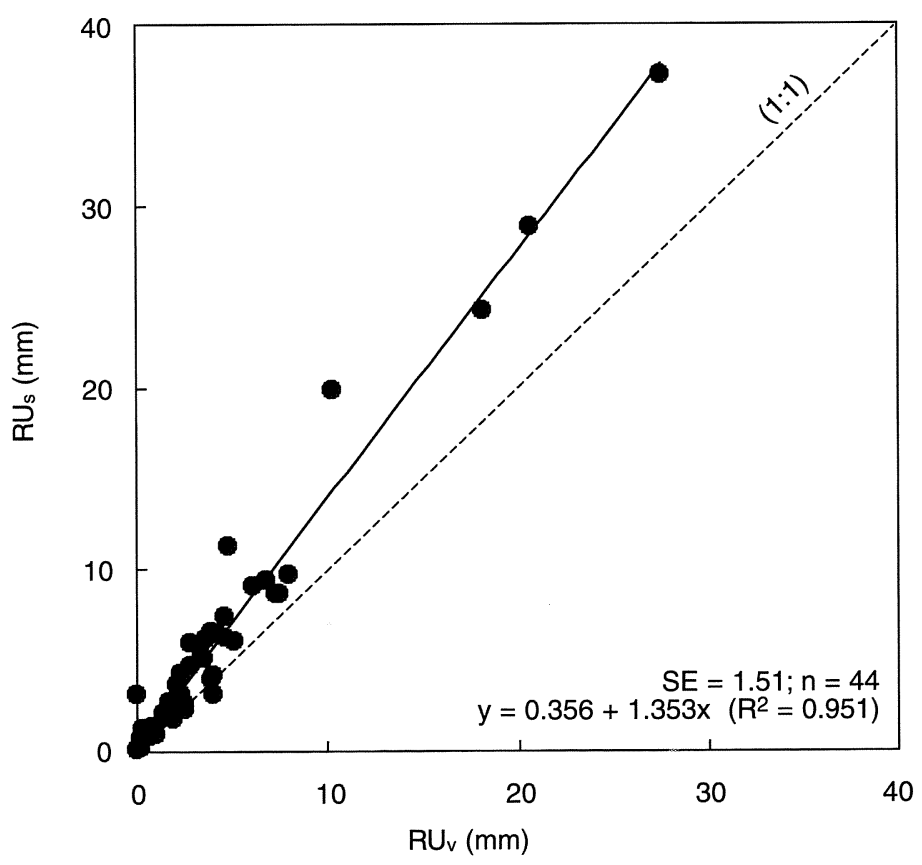

FIGURE 2

Relationship between mean daily rainfall measured under slanting canopies $\left(R U_{S}\right)$ and vertical canopies $\left(\mathrm{RU}_{\mathrm{v}}\right)$. Data were collected over two seasons at Nietvoorbij, Stellenbosch. 
interception tended to increase and decrease as the vegetative growth changed over the season.

Due to the above-mentioned effects on rainfall interception, rainfall recorded below the canopy was related to rainfall outside the vineyard and day of season by means of multiple linear regression. Since there were no significant differences in rainfall interception between the three slanting canopies, data were pooled. Data for the vertical canopies were treated in a similar way. Furthermore, it was assumed that canopy development is a second-order polynomial function of time expressed as day of season (DOS), where 1 September was regarded as day 1. Data for the two seasons were also pooled, resulting in 44 observations. The following regression equations explained $96 \%$ and $89 \%$ of rainfall variation under slanting and vertical canopies, respectively:

$\mathrm{RU}_{\mathrm{s}}=0.86 \mathrm{R}-0.026 \mathrm{DOS}+0.00007 \mathrm{DOS}^{2} \quad\left(\mathrm{n}=44 ; \mathrm{SE}=1.4, \mathrm{R}^{2}=0.9607\right)$ and

$\mathrm{RU}_{\mathrm{v}}=0.80 \mathrm{R}-0.041 \mathrm{DOS}+0.0001 \mathrm{DOS}{ }^{2} \quad\left(\mathrm{n}=44 ; \mathrm{SE}=2.0, \mathrm{R}^{2}=0.8923\right) \quad(2)$

where $R$ is daily rainfall measured outside the vineyard and $R U_{S}$ and $\mathrm{RU}_{\mathrm{v}}$ are estimated rainfall under slanting and vertical canopies, respectively. For both equations the three independent variables made a significant $(p<0.01)$ contribution to the estimation of rainfall under the canopies. Coefficients of equations 1 and 2 indicated that at least $14 \%$ and $20 \%$ of the daily rainfall were intercepted by slanting and vertical canopies, respectively.

Using equation 1 , it could be estimated that, if $20 \mathrm{~mm}$ rainfall occurred on 15 December, $15.2 \mathrm{~mm}$ will reach the soil surface under a slanting canopy. If it is assumed that the canopy covers $80 \%$ of the total area, the mean weighted amount of water that reaches the soil surface will amount to $16.2 \mathrm{~mm}$, i.e. [(15.2 $\mathrm{mm} \mathrm{x} \mathrm{80)+(20} \mathrm{mm} \mathrm{x}$ $20)] / 100$. Under the same conditions, $12.9 \mathrm{~mm}$ rainfall would penetrate through a vertical canopy. Mean weighted amount of water that reaches the soil surface would amount to $18.6 \mathrm{~mm}$, i.e. [(12.9 $\mathrm{mm} \times 20)+(20 \mathrm{~mm} \times 80)] / 100$, if it assumed that $20 \%$ of the interrow space is covered by the canopy. These calculations indicated that mean weighted rainfall in a vineyard with a fully developed canopy would not differ drastically from actual rainfall.

\section{CONCLUSIONS}

Slanting as well as vertical grapevine canopies intercepted surprisingly little daily rainfall. This, as well as the fact that rainfall in the centre of the work row was virtually the same as rainfall outside the vineyard, indicated that rainfall in vineyards did not differ significantly from actual rainfall. Considering the fact that it would be almost impossible to measure all the variables influencing effective rainfall in vineyards, the two models developed to estimate effective rainfall under slanting and vertical canopies, respectively, should only be regarded as a first approach. Quantification of the amount of rainfall that penetrates the soil, but evaporates before it can be absorbed by grapevine roots, would make a meaningful contribution to estimation of effective rainfall. However, such studies will require special equipment to measure changes in water content near the soil surface accurately and continuously.

\section{LITERATURE CITED}

Archer, E. \& Booysen, J.H., 1987. Prieelstelsels vir druiwe. Wynboer Tegnies 21, 3-14.

Dent, M.C., Schulze, R.E. \& Angus, G.R., 1988. Crop water requirements, deficits and water yield for irrigation planning in Southern Africa. WRC Report No. 118/1/88, Water Research Commission, Pretoria, 184p.

Green, G.C., 1985. Estimated irrigation requirements of crops in South Africa, Part 1. Memoirs on the Agricultural Resources of South Africa, No. 2. Dept. Agriculture and Water Supply, Pretoria, 409p.

Myburgh, P.A., 1998. Water consumption of South African vineyards: A modelling approach based on the quantified combined effects of selected viticultural, soil and meteorological parameters. Dissertation, Stellenbosch University, Private Bag X1, 7602 Matieland (Stellenbosch), South Africa.

Saayman, D. \& Lambrechts, J.J.N., 1995. The effect of irrigation system and crop load on the vigour of Barlinka table grapes on a sandy soil, Hex River Valley. S. Afr. J. Enol. Vitic. 16, 26-34.

Van Zyl, J.L., 1981. Besproeiing. In: Burger, J.D. \& Deist, J. (eds). Wingerdbou in Suid-Afrika. Nietvoorbij, Stellenbosch, South Africa. pp. 234-282.

Volschenk, C.G. \& Hunter, J.J., 2001. Effect of trellis conversion on the performance of Chenin blanc/99 Richter grapevines. S. Afr. J. Enol. Vitic. 22, 31-35.

Zeeman, A.S., 1981. Oplei. In: Burger, J.D. \& Deist, J. (eds). Wingerdbou in SuidAfrika. Nietvoorbij, Stellenbosch, South Africa. pp. 185-201. 